Review Article

\title{
Development of Theater Education Textbook with Character Education and Local Wisdom Through Active Learning to Improve the Students' Script Writing Ability
}

\author{
Muh. Ismail ${ }^{1}$, Retno Winarni ${ }^{2, *}$ \\ ${ }^{1}$ Sebelas Maret University, Surakarta, Indonesia \\ ${ }^{2}$ Sebelas Maret University, Surakarta, Indonesia \\ Received 09 December 2018 \\ Revised 29 July 2019; Accepted 11 September 2019
}

\begin{abstract}
The purposes of this study are to describe: (1) the students' and lecturers' needs on the Theater Education Textbook, (2) the development of the textbook model, (3) the effectiveness testing on the designed textbook, and (4) the result of the textbook dissemination. This research was Research and Development using Borg and Gall's framework that consisted of 4 stages: (1) exploration, (2) model development, (3) model testing, and (4) dissemination. The research approach used in the exploration stage was a qualitative descriptive approach. The data were collected through documentation study, observation, in-depth interview, and questionnaire. The data were then analyzed by using interactive analysis model. Model testing was done by experimental research. The results of this research were: (1) the exploration stage showed that the Theater Education Textbook used in Undergraduate Elementary Teacher Education (ETE) Program of Sebelas Maret University, Muhammadiyah University, and Slamet Riyadi University Surakarta did not meet the students' and lecturers' needs, (2) the theater education textbook was developed through preliminary field testing; and (3) testing phase of textbook effectiveness was done through main field testing. The value of t-obtained is 0.17 and t-table $(0.05 ; 173)=1.64$. Thus, the critical area $\{\mathrm{t}<-1.64$ or $\mathrm{t}>1.64\}$. Since $\mathrm{t}$-obtained $(0.17)<\mathrm{t}$-table $(1.64) \mathrm{H} 0: \mu 1 \neq \mu 2$ was accepted. This means that the theater script writing textbook with character education and local wisdom was able to improve the students' scriptwriting ability.
\end{abstract}

Keywords: Textbook, theater script writing, character education, local wisdom, active learning.

\section{Introduction}

The phenomenon of less successful teaching of theater education in Elementary

\footnotetext{
* Corresponding author.

E-mail address: i_smile48@yahoo.co.id

https://doi.org/10.25073/2588-1159/vnuer.4205
}

Teacher Education (ETE) Program can be caused by the low level of scriptwriting skill. The more implicit reason was, among others, the limitation of textbooks. The existing or commonly used reference books had not fully supported the success of student theater education lessons. The ability to write a theater script could be mastered well if it is supported 
by the understanding and mastering of the scriptwriting techniques. Theater as a work of art has the value of form, sensory, knowledge, and life. In an effort to achieve the aesthetics of the art figure, we should not sacrifice the moral aspect. On the one hand, the moral aspect must exist in every theater work. By theater, society could be educated, directed, and influenced. Moral and art should be transmitted to form the character and moral of the next generation (Sumaryadi, 1987) [1].

For that reason, students need to have knowledge about theater script writing techniques and character education as well as the students also need to understand local wisdom that can be associated with theater script writing. Based on the observation on three university, the authors found that the appropriate textbook for writing theater script is unavailable. The learning material regarding writing script of theater script writing was still grouped in Indonesian language learning. This makes the students feel confuse to learning theater scriptwriting. Perceive on the results of the exploratory stage on the students' and lecturers' need, Theater Script Writing Textbook with character education and local wisdom was highly needed.

Based on that problem, this research aims to develop theater education textbook with character education and local wisdom through active learning can develop students' script writing ability. The developed textbook is expected to support

\section{Theoretical review}

\subsection{Character education}

According to Mustari (2014) [2], planting character values is a fundamental effort to improve the quality of future generations of the nation. In the context of Indonesian education system, the character values developed based on 18 indicators: religious, honesty, tolerance, discipline, hard work, independence, creativity, democratic, curiosity, spirit of nationality, love of the nation, appreciate achievement, friendly, peaceful, love to read, care of the environment, care of the social condition, and responsibility. In order to implement those character values, among others, it can be done through learning to write a theater script. Ulum (2014) [3] stated that important character education was instilled to equip students to learn independently. According to Asma (2014) [4], the values of the characters included religious values, social norms, rules or laws, academic ethics, and human rights principles. Those values can be classified into five main values, namely: the values of human behavior to God, the values to himself, the values to the fellow human beings, the values to the environment, and the values to the nationality. Wibowo (2012) [5] revealed that the noble values contained in the customs and cultures of our tribes have been studied and summarized.

Based on that study, it has been identified the noble values that are internalized to the nation generation through character education. The values are religious, honesty, discipline, hard work, creative, independence, friendliness, peace-loving, caring, and responsibility.

\subsection{Local wisdom}

Geertz (1973) [6] stated that local wisdom is part of the culture. Furthermore, Geertz stated that local wisdom is a basic element of culture in human life and society that deals with human, cultural, economic, security, and rule of law. Local wisdom is the intellectual property of the local region in the form of knowledge, beliefs, norms, customs, culture, insight and so forth. Local wisdom is an inheritance and is maintained as an identity and guidance in teaching people to act appropriately in life. According to Utari, Dedeng and Akbar (2016) [7], local wisdom has the following features and functions: (1) as an identity marker of a community; (2) as an adhesive element of social cohesion; (3) as an element of culture that grows from below, exists and develops in society; and not a forced element from above; (4) serves to provide a sense of togetherness for 
a particular community; (5) can change the mindset and reciprocity of individuals and groups by putting it on a common ground; and (6) able to encourage the building of togetherness, appreciation, and mutual mechanisms to defend themselves from the possibility of disturbance or destruction toward group solidarity as a whole and integrated community. The next generations of the nation need to instill a sense of love for the culture of their region, one way that can be done is by implement local wisdom in classroom learning (Panjaitan et al., 2014) [8].

Based on that description, it can be summed up that local wisdom refers to the intellectual property existed in society. Local wisdom is very important to be preserved and the value needs to be implemented in learning. This is important because the value of local wisdom can be used as a guideline of the learner's behavior toward a more positive direction. Local wisdom can encourage young people to love, proud, and conserve local wealth.

\subsection{Active learning}

Active learning refers to the activities that help students to test their feelings, values, and behaviors (Silberman, 2006) [9]. Silberman describes that in active learning, students can do a lot of activities. They use their brains to learn ideas, solve problems, and apply what they have learned. According to Lorenzen (2001), active learning is a method in educating or inviting students to participate actively in the classroom. Active learning aims to optimize the use of all potential possessed by students so that all students can achieve satisfactory learning outcomes according to their personal characteristics. Therefore, learning to write a theater script needs to be done through active learning. Cherney (2008) [10] reveals that the application of active learning depends on the level of the program, the material, the type of student, the type of class, as well as the discussion required by the students to improve the understanding of the material. The application of active learning is needed to improve theater scriptwriting skill. Meyers and Jones' research (1993) [11] conclude ed that by applying active learning strategies, students can express four language skills: listening, speaking, reading, and writing.

Prince's research (2004) [12] concluded that the selection of an active learning strategy is an appropriate consideration to make learning effective. Active learning is an effective teaching technique compared to conventional teaching techniques. The advantages of active learning are: (1) students will learn more material; (2) the student may keep the information longer; and (3) students like learning, faculty, and class conditions more as it is something new and variation. Based on the theoretical review, it can be highlighted that active learning allows students to study in the classroom with the help of lecturers or without lecturers, and other students.

\subsection{Theater script writing textbook}

Theater Script Writing textbook with educational character and local wisdom was expected to support the students' success in learning theater script writing. Students' ability to write a theater script can be increased if Theater Script Writing textbook with character education and local wisdom is available for the learning process. According to the national standard, a good textbook must meet the following standards: (1) in accordance with the basic competence and standard competence; (2) covers the time span of its use; (3) includes the capital, metropolis, and regional authors; (4) in accordance with the principles of multiculturalism; and (5) easy to understand (Djanali, 2007) [13].

The textbook contains specific materials used as a teaching and learning guidance at school (Richards \& Rodgers, 2002) [14]. Textbooks are usually used in conjunction with other learning resources such as workbooks, teacher reference books or supporting textbooks (Tomlinson \& Masuhara, 2008) [15]. For the purpose of fulfilling the need of Theater Script Writing textbook with character education and 
local wisdom, this research was urgently needed to be done in the Elementary Teacher Education (ETE) Program in Surakarta.

Based on the above description regarding the concept active learning, it can be assumed that the theater education textbook with character education and local wisdom through active learning can develop students' script writing ability.

\section{Research hypothesis}

The research hypothesis is that the theater education textbook with character education and local wisdom through active learning can develop students' script writing ability.

\section{Research method}

This research was conducted by following the research and development procedures $(\mathrm{R} \&$ D) that was developed by Borg and Gall (2003) [16]. Borg and Gall argued that R \& D is a process used to develop and validate educational products. Seals and Richey (1994) stated that R \& D as a systematic review of the design, development, and evaluation of programs, processes and learning products that must meet the criteria of validity, practicality, and effectiveness. In line with this, Plomp (1999) added the criteria of that can show additional value.

According to Borg and Gall (2003), 10 steps of R \& D are: (1) exploration study, (2) planning, (3) design development, (4) preliminary field test, 5) revision of limited field test results, (6) main field test, (7) revision of main field test result, (8) feasibility test, (9) final revision of feasibility test, (10) dissemination and implementation of final product. Those steps were then summarized into 4 main stages, each of which includes several operational steps. The four main steps are (1) the exploration stage, (2) the model development stage, (3) the model testing stage, and (4) the dissemination and implementation of the model stage (Sukmadinata, 2010 [17]; Nurkamto, 2012) [18].

Exploration stage was done by the in-depth study on the implementation of Theater Education learning process in undergraduate ETE Program in Surakarta area. The purpose of this activity was to analyze the students' and lecturers' needs on Theater Scripts Writing Textbook with character education and local wisdom which was considered capable in improving the students' ability to write theater script optimally. The research approach used was a qualitative descriptive approach. Researchers emphasized the observation of the interaction between students and lecturers in the execution of writing theater script learning in the research location. Researchers also conducted in-depth interviews and questionnaires toward students and lecturers and also analyzing documents relating to research problems.

The data of this study were obtained from various data sources available at the study sites. Types of data sources used were 5 students and 5 lecturers, theater script learning activities in the classroom, and documents or archives. The data were collected through documentation, observation, in-depth interviews, and questionnaires. Data analysis of this research was conducted with interactive analysis model (Miles and Huberman 1992 [19]; Sutopo, 2002) [20], which was carried out in 2 stage, namely: analysis during data collection and analysis after data collection.

The main objective of the development stage was to produce the textbook model. The developed prototype of the textbook was cyclical, which was a combination of research and practice (Borg and Gall, 2003) [16]. The steps taken included the preparation of prototype, implementation, evaluation of implementation, and revision in a sustainable manner. The procedure used was the Glanz model theory (in Borg and Gall, 2003) [16], which includes data collection, analysis, data interpretation, reflection, and modification. In addition, the Zuber-Skeritt model was also used (in Cohen, 2000) [21], which includes careful 
planning, implementation of plans, observation, assessment, evaluation, critical analysis of implementation results, and subsequent cycle determination.

The development was done by testing the textbook prototype in the field through limited trials and extensive trials. A limited trial was conducted in the undergraduate ETE Program of Sebelas Maret University Surakarta. Extensive trials were conducted in the undergraduate ETE Program of Muhammadiyah University Surakarta and Undergraduate ETE Program of Slamet Riyadi University Surakarta. Data collection techniques were document analysis, participant observation, in-depth interviews, tests and focus group discussions. Data analysis was done in two ways: qualitative and quantitative. The model that had been tested was then consulted with the expert in order to verify that the developed textbook model has substantive truth and quality. The validation was done by Prof. Dr. H.J. Waluyo (expert of theater arts education) lecturer of Sebelas Maret University Surakarta.

The testing phase of the developed model was aimed to test the effectiveness of the textbook model in improving the students' ability to write theater script. Model testing was done by conducting experimental research. The type of experimental research used was the Quasy-Experimental Model of Non-equivalent before-after Design (Wiersma, 1986 [22]; Cohen et al. 2000 [21]; Sugiyono 2013) [23]. The experimental procedures used were the concepts of Gall, Gall, \& Borg (2003) [16] and Cohen (2000). The experimental class was 90 students of undergraduate ETE Program of Sebelas Maret University Surakarta. The control class was 85 students of undergraduate ETE Program of Muhammadiyah University Surakarta. This study was looking at the main effect of the textbook model on the students' ability to write a theater script. Data collection techniques were a test on the ability to write theater script. The analysis of the research data was done through two stages, namely the requirements analysis test stage (normality test, homogeneity test, and balance test) and the data analysis stage to test the effectiveness of the model, such as by the mean difference test (independent t-test). The output of the model testing phase was the Theater Script Writing textbook with character education and local wisdom that has been tested in a process and in a product.

This dissemination phase was done by disseminating the Theater Script Writing textbook with character education and local wisdom that had been developed. The textbook can be implemented on theater script writing lesson especially in universities which have undergraduate ETE Program. Furthermore, the dissemination was done through national seminars, writing articles in international journals, as well as the publication of the textbook with ISBN.

\section{Result and discussion}

Based on the findings at the exploration stage, it could be concluded some problems in the theater arts education learning process in the Elementary Teacher Education Program (ETEP). The problems were (1) the absence of Theater Script Writing textbook with character education and local wisdom, (2) there was no action to improve the students' theater scriptwriting skill, (3) the lecturers did not understand the theater script writing material, and (4) lecturers had not used innovative learning models yet. In principle, students, lecturers, and policymakers agreed that the Theater Script Writing textbook with character education and local wisdom needed to be developed immediately. Furthermore, based on the need analysis of the students and lecturers, the following results were obtained (1) Theater Scripts Writing textbook with character education and local wisdom should be prepared to facilitate and guide students to improve their theater scriptwriting skill, (2) innovative learning procedures such as active learning was necessary to be applied as a solution to the students' saturation in monotonous and non-varied lectures, 
and (3) the need to use local culture as a learning resource that can help improving the students' theater script writing skills.

Six steps to be done based on the findings of the exploratory stage, namely: (1) developing prototype into the textbook model of Theater Script Writing with character education and local wisdom, (2) validating prototype development model through expert judgment, (3) validating the model through limited trial in undergraduate ETE Program in Surakarta, (4) validating the model through broader trials in undergraduate ETE Program in Surakarta, (5) deciding the final textbook models, and (6) concluding the development result.

This research data was in a form of the theater scriptwriting skill score of undergraduate ETE Program students in Surakarta which was used as a research sample, both for experimental class and control class. In the experimental class, 90 respondents who come from the students of undergraduate ETE Program of Sebelas Maret University Surakarta participated. They were treated by using the textbook model of Theater Script Writing with character education and local wisdom through active learning. On the contrary, 85 respondents from the control class who came from the undergraduate ETE Program students of Muhammadiyah University Surakarta who were treated by using the conventional textbook model.

Referring to the above explanation, the total number of respondents was 175 , in total of 90 respondents in the experimental class, and 85 other respondents in the control class. In the experimental and control classes, all respondents were given the test on the ability to write the theatrical script before treatment (pretest) and after treatment (post-test).

Based on the above description, the description of the research data was grouped into 6 parts: (1) pre-test score data on the students' ability to write theater script in the experimental class; (2) post-test score data on the students' ability to write theater script in the experimental class; (3) pre-test post-test deviation score data on the students' ability to write theater script in the experimental class (4) pre-test score data on the students' ability to write theater script in the control class; (5) posttest score data on the students' ability to write theater script in the control class; and (6) pretest post-test deviation score data on the students' ability to write theater script in the control class. The data group would also describe its statistical quantities that include: (1) the calculation of central tendencies, such as: mean, median, mode; (2) the calculation of the spread tendency, such as: variance, and standard deviation; (3) the highest score; (4) the lowest score; (5) range; (6) the result of frequency distribution; and (7) the histogram image of the frequency score.

\subsection{Pre-test score data of the experimental class}

Based on the descriptive analysis conducted with Excel 2013 program, the pre-test score of 90 ETEP students of Sebelas Maret University Surakarta as the experiment class could be reported: (1) central tendency: mean $=68.81$, mode $=67$, and median $=68 ;$ (2) spread tendency: variance $=11.89$, and standard deviation $=3.45$; (3) the highest score $=77$; and the lowest score $=59 ;(4)$ range $=18$.

Frequency distribution of the pre-test score of students' theater writing skill was obtained through calculation steps as follows:

1. Determine the range by reducing the highest score with the lowest score: $77-59=18$

2 . Determine the number of interval classes. In this study 5 interval classes were used

3. Determine the length of the interval class by dividing the range by the number of interval classes; $18: 5=3.6$ which then rounded to 4 .

4. Choose the lower end of the first interval class. This was done by taking the lowest score. Therefore, the first interval of class starts from 59.

Based on the steps of preparing the frequency distribution, the frequency distribution of the pre-test score of the students' ability to write theater script could be seen in Table 1. 
Table 1. pre-test score frequency distribution of the experiment class

\begin{tabular}{lcc}
\hline Interval Class & absolute frequency $\left(\mathrm{f}_{\text {abs }}\right)$ & relative frequency $(\%)\left(\mathrm{f}_{\text {rel }}\right)$ \\
\hline $59-62$ & 3 & 3,33 \\
$63-66$ & 19 & 21,11 \\
$67-70$ & 39 & 43,33 \\
$71-74$ & 24 & 26,67 \\
$75-78$ & 5 & 5,56 \\
& 90 & 100,00 \\
\hline
\end{tabular}

\subsection{Post-test score data of experimental class}

Based on the descriptive analysis conducted with Excel 2013 program, the post-test score of 90 ETEP students of Sebelas Maret University Surakarta as the experiment class could be reported: (1) central tendency: mean $=77.68$, mode $=75$, and median $=77$; (2) spread tendency: variance $=23.97$, and standard deviation $=4.90 ;(3)$ the highest score $=88$; and the lowest score $=68$; (4) range $=20$. As the stages of preparing the frequency distribution of the pre-test scores described above, the same calculation was done to the post-test data. The result was: (1) range $=88-68=20$; (2) number of interval classes were set 6 ; (3) the interval class length $20: 6=3.33$ rounded up to 4 ; and (4) the lower end of the first interval class starts from the smallest data of 68 .

Based on the above calculation, the frequency distribution of the post-test score of the students' ability to write theater script could be seen in Table 2.

Table 2. Frequency Distribution of the post-test score in the experiment class

\begin{tabular}{lcl}
\hline Interval Class & absolute frequency $\left(\mathrm{f}_{\mathrm{abs}}\right)$ & relative frequency $(\%)\left(\mathrm{f}_{\text {rel. }}\right)$ \\
\hline $68-71$ & 9 & 10,00 \\
$72-75$ & 26 & 28,89 \\
$76-79$ & 23 & 25,56 \\
$80-83$ & 18 & 20,00 \\
$84-87$ & 13 & 14,44 \\
$88-91$ & 1 & 1,11 \\
& 90 & 100,00 \\
\hline
\end{tabular}

5.4. Pre-test post-test deviation score data of the experiment class

Based on the descriptive analysis conducted with Excel 2013 program, the pre-test post-test deviation score of 90 ETEP students of Sebelas Maret University Surakarta in the experiment class could be reported: (1) central tendency: mean $=8.87$, mode $=6$, and median $=8.5 ;(2)$ spread tendency: variance $=13.76$, and standard deviation $=3.71$; (3) the highest score $=17$; and the lowest score $=2$; (4) range $=15$. As the stages of preparing the frequency distribution of the pre-test scores described above, the same calculation was done to the post-test data. The result was: (1) range $=17-2=15$; (2) number of interval classes were set 6 ; (3) the interval class length 15 : $6=2.5$ rounded up to 3 ; and (4) the lower end of the first interval class starts from the smallest data of 2 .

Based on the above calculation, the frequency distribution of the pre-test post-test deviation score of the students' ability to write a theater script could be seen in Table 3 . 
Table 3. frequency distribution of the pre-test post-test deviation in the Experimental class

\begin{tabular}{lll}
\hline Interval Class & absolute frequency $\left(\mathrm{f}_{\text {abs }}\right)$ & relative frequency $(\%)\left(\mathrm{f}_{\text {rel. }}\right)$ \\
\hline $2-4$ & 10 & 11,11 \\
$5-7$ & 25 & 27,78 \\
$8-10$ & 27 & 30,00 \\
$11-13$ & 17 & 18,89 \\
$14-16$ & 7 & 7,78 \\
$17-19$ & 4 & 4,44 \\
& 90 & 100,00 \\
\hline
\end{tabular}

\subsection{Pre-test score data of the control class}

Based on the descriptive analysis conducted with Excel 2013 program, pre-test score data of 85 undergraduate ETEP students of Muhammadiyah University Surakarta in control class could be reported as: (1) central tendency: mean $=63.81$, mode and median $=63 ;(2)$ spread tendency: variance $=12.70$, and standard deviation $=3.56$; (3) the highest score $=72$; and the lowest score $=54$; (4) range $=18$. The preparation of the frequency distribution of the control class pre-test scores data obtained: (1) range $=72-54=18 ;(2)$ many interval classes are set 5 ; (3) the interval class length 18: $5=$ 3.6 rounded up to 4 ; and (4) the lower end of the first interval class started from the smallest data of 54.

From the above calculation, the frequency distribution of the pre-test score of the control class students' ability to write theater script could be seen in Table 4 .

Table 4. frequency distribution of the pre-test score in the control class

\begin{tabular}{llc}
\hline Interval Class & absolute frequency $\left(\mathrm{f}_{\text {abs }}\right)$ & relative frequency $(\%)\left(\mathrm{f}_{\text {rel }}\right)$ \\
\hline $54-57$ & 4 & 4,71 \\
$58-61$ & 18 & 21,18 \\
$62-65$ & 37 & 43,53 \\
$66-69$ & 20 & 23,53 \\
$70-73$ & 6 & 7,06 \\
& 85 & 100,00 \\
\hline
\end{tabular}

\subsection{Post-test score data of the control class}

Based on the descriptive analysis conducted with Excel 2013 program, post-test score data of 85 undergraduate ETEP students of Muhammadiyah University Surakarta in control class could be reported as: (1) central tendency: mean $=72.78$, mode $=70$ and median $=73 ;(2)$ spread tendency: variance $=13.36$, and standard deviation $=3.67 ;$ ( 3 ) the highest score $=80$; and the lowest score $=65$; (4) range $=15$. The preparation of the frequency distribution of the control class pre-test scores data obtained: (1) range $=80-65=15$; (2) many interval classes are set 6 ; (3) the interval class length 15:6 $=2.5$ rounded up to 3; and (4) the lower end of the first interval class started from the smallest data of 65 .

From the above calculation, the frequency distribution of the post-test score of the control class students' ability to write theater script could be seen in Table 5 . 
Table 5. Frequency Distribution of the post-test score in the control class

\begin{tabular}{lcc}
\hline Interval Class & absolute frequency $\left(\mathrm{f}_{\text {abs }}\right)$ & relative frequency $(\%)\left(\mathrm{f}_{\text {rel. }}\right)$ \\
\hline $65-67$ & 6 & 7,06 \\
$68-70$ & 22 & 25,88 \\
$71-73$ & 20 & 23,53 \\
$74-76$ & 20 & 23,53 \\
$77-79$ & 16 & 18,82 \\
$80-82$ & 1 & 1,18 \\
& 85 & 100,00 \\
\hline
\end{tabular}

5.7. Pre-test post-test deviation score data of the control class

Based on the descriptive analysis conducted with Excel 2013 program, pre-test post-test deviation score data of 85 undergraduate ETEP students of Muhammadiyah University Surakarta in control class could be reported as: (1) central tendency: mean $=8.96$, mode $=8$ and median $=9$; (2) spread tendency: variance $=11.92$, and standard deviation $=3.45$; $(3)$ the highest score $=17$; and the lowest score $=2 ;(4)$ range $=15$. The preparation of the frequency distribution of the control class pre-test scores data obtained: (1) range $=17-2=15$; (2) many interval classes are set 6; (3) the interval class length $15: 6=2.5$ rounded up to 3 ; and (4) the lower end of the first interval class started from the smallest data of 2 .

From the above calculation, the frequency distribution of the pre-test post-test deviation score of the control class students' ability to write theater script could be seen in Table 6 .

Table 6. Frequency distribution of the pre-test post-test deviation score of the control class

\begin{tabular}{lll}
\hline Interval Class & absolute frequency $\left(\mathrm{f}_{\mathrm{abs}}\right)$ & relative frequency $(\%)\left(\mathrm{f}_{\text {rel. }}\right)$ \\
\hline $2-4$ & 8 & 9,41 \\
$5-7$ & 22 & 25,88 \\
$8-10$ & 29 & 34,12 \\
$11-13$ & 18 & 21,18 \\
$14-16$ & 4 & 4,71 \\
$17-19$ & 4 & 4,71 \\
& 85 & 100,00 \\
\hline
\end{tabular}

\section{Requirement analysis testing}

The inferential data analysis used to prove the research hypothesis was accepted or rejected was the independent t-test. This statistical data analysis needs to meet several requirement analysis: (1) normality test, (2) homogeneity test, and (3) balance test. Normality test was done using the Lilliefors technique, while the homogeneity of variance test was done using Bartlett's analysis, and the balance test was done using the independent t-test.

\subsection{Normality Test}

As mentioned in the above statements, the data tested by normality in this research were divided into two sections: (1) pre-test post-test score data of students' writing skill in the experiment group, and (2) pre-test post-test score data of students' writing skill in the control group. The result of the normality test for both groups of data above can be seen in the following description. 
Normality test for pre-test and post-test deviation score data of experimental class

Normality test toward pre-test post-test deviation score data in the experimental class showed maximum Lo of 0.0910. From the list of critical $\mathrm{L}$ for the Lilliefors test with $\mathrm{n}=90$ and real level $\alpha=0.05$, it is obtained $\mathrm{Lt}=$ 0.0934 . From the above comparison, it could be stated that Lo was smaller than Lt, thus it could be stated that the pre-test post-test deviation score data of the experiment class came from a population with the normal distribution.

Normality test for pre-test post-test deviation score data of control class

Normality test toward pre-test and post-test deviation score data in the control class showed maximum Lo of 0.0927. From the list of critical $\mathrm{L}$ for the Lilliefors test with $\mathrm{n}=85$ and real level $\alpha=0.05$, it is obtained $\mathrm{Lt}=0.0961$. From the above comparison, it could be stated that Lo was smaller than Lt, thus it could be stated that the pre-test post-test deviation score data of the control class came from a population with the normal distribution.

\subsection{Homogeneity of variance test}

This homogeneity of variance test was conducted to test the similarity of variance between the pre-test score and the post-test score of students' writing skill in experimental group and control group. The statistical technique used for this purpose is Bartlett's test technique. The test was intended to test the null hypothesis ( $\mathrm{H} 0)$ that stated the variance of pretest post-test score between experimental class and control class was homogeneous on the real level $\alpha=0.05$ against the alternative hypothesis (H1), which stated that between the variance of pre-test post-test score of the experimental class and the control class was not homogeneous at the same real level.

The test criterion used is that $\mathrm{HO}$ is rejected if it turns out smaller or equal to the real level $\alpha$ $=0.05$. Conversely, if $\mathrm{HO}$ is higher than the real level $\alpha=0.05$, then $\mathrm{H} 0$ was accepted which means that the variance score was homogenous.
The test criterion used was that $\mathrm{H}_{0}$ is rejected if it turns out that $\chi_{\text {obtained }}^{2}$ is smaller or equal to $\chi_{\text {table }}^{2}$ at the real level $\alpha=0.05$. Conversely, if $\chi_{\text {obtained }}^{2}$ is higher than $\chi_{\text {table }}^{2}$ at the real level $\alpha=0.05$, then $\mathrm{H}_{0}$ was accepted which means that the variance score was homogenous.

Homogeneity test between variance of pretest post-test enumeration score of students' writing skill in the experimental group and the control group resulted in $\chi_{\text {obtained }}^{2}=0.46$. From the chi-squared distribution table with $\mathrm{df}$ (degrees of freedom) 1 and the real level $\alpha=$ 0.05 obtained $\chi_{\text {table }}^{2}=3.84$ which was much larger than $\chi_{\text {obtained }}^{2}$. Thus, based on the testing criterion, the null hypothesis ( $\mathrm{H} 0)$ which stated that the variance of pre-test post-test score of the students' ability to write theater script in the experimental group and the control group is homogenous was accepted. The conclusion is that the variance of pre-test post-test score deviation in the students' ability to write theater script in both groups was homogeneous.

\subsection{Balance test}

The balance test aims to test the average equation of students' theater scriptwriting skill between the experimental group and the control group. The statistical test used is t-test with the real level $\alpha=0.05$. Hypothesis proposed: $\mathrm{H}_{0}$ if $\mathrm{t}$ obtained $>t$ table then the students' variance score of the ability to write the theater script of both groups are not balanced. $\mathrm{H}_{1}$ if the $\mathrm{t}_{\text {obtained }}<\mathrm{t}$ table then the students' variance scores of both groups were balanced. The test result showed that $\mathrm{t}_{\text {obtained }}$ $=-0.0037<\mathrm{t}$ table $=1.645$. It could be concluded that the average score of the students' ability to write a theater script of the experimental group and the control group was balanced.

\section{Hypothesis testing}

Hypothesis testing here means to know whether the proposed null hypothesis $\left(\mathrm{H}_{0}\right)$ is rejected, or vice versa at certain level of 
confidence the proposed alternative hypothesis $\left(\mathrm{H}_{1}\right)$ is accepted. In accordance with the aforementioned description in the previous section, the research hypotheses were tested by independent t-test technique. The technique of statistical analysis was used to observe the effectiveness of the treatment in the use of the textbook model, with those who did not use the textbook model. The effectiveness of the textbook model to improve the ability to write a theater script of ETEP students in Sebelas Maret University Surakarta and Muhammadiyah University Surakarta areas was tested.

Based on statistical analysis with independent t-test technique, it showed that $\mathrm{t}$ obtained was 0.17 . Meanwhile, the critical area: $\mathrm{t}_{(0.05: 173)}=1.64$ so critical area: $\{\mathrm{t}<-1.64$ or $\mathrm{t}\rangle$ $1.64\}$. It could be seen that $\mathrm{t}$ obtained $=0.17<\mathrm{t}$ table so $\mathrm{H}_{0}$ was accepted. Thus, there was a significant difference between the ability to write a theater script of students who were taught using the textbook model and the students who were taught using the used textbook. In other words, it could be concluded that the theater script writing textbook with character education and local wisdom through active learning could improve the students' ability to write a theater script.

The implementation of active learning supports theater education learning to improve the students' ability to write theatrical script optimally. Cherney (2008) concluded that the application of active learning was based on the level of the program, the material, the type of students, the type of class, and the discussion required by the students to improve the understanding of the material. The application of active learning is needed to improve the understanding of the material of the theatrical scriptwriting skill. Meyers \& Jones (1993) concluded that by the application of active learning strategies, students could express four language skills: listening, speaking, reading, and writing. Thus, the application of active learning in the theater education learning by using theater script writing textbook with character education and local wisdom was effective to improve the ability to write theater script.

\section{Conclussion}

The exploratory stage showed that theater script writing textbook with character education and local wisdom has not been used in the undergraduate ETE Program of UNS, UMS, and UNISRI Surakarta. The model development stage produced theater script writing textbook with character education and local wisdom through preliminary field testing. Testing the effectiveness of the textbook model was done through main field testing. The value of $t_{\text {obtained }}$ was 0.17 meanwhile the critical area: $\mathrm{t}_{(0.05: 173)}=1.64$; ca $\{\mathrm{t}<-1,64$ or $\mathrm{t}>1.64\}$ thus $\mathrm{t}$ obtained $(0.17)<$ ca so Ho: $\mu 1 \neq \mu 2$ was accepted. The dissemination stage was done through socializing the textbook in national seminars, international journals, and published the theater script writing textbook with character education and local wisdom with ISBN. The theater script writing textbook with character education and local wisdom effectively improve the students' theater script writing skills. The textbook could be accepted by lecturers, policy makers, and students as teaching materials.

\section{References}

[1] Sumaryadi, “Aduh” Karya Putu Wijaya Sebuah Drama Kontemporer dan, 1987.

[2] Mustari, Nilai Karakter untuk Refleksi Pendidikan, Jakarta: Raja Grafindo Persada, 2014.

[3] Ulum, Wisda Miftakul, Pengembangan Buku Teks Membaca Intensif Berbasis Karakter di Sekolah dasar, Jurnal Pendidikan Humaniora 2 (2) (2014) 130-134.

[4] Asma, Jamal Mamur, Buu Pandua Internalisasi Pendidikan Karakter di Sekolah Dasar. Yogyakarta: Diva Press, 2014.

[5] Wibowo, Agus, Manajemen pendidikan Karakter Sekolah Dasar, Jakarta: PT Rineka Cipta, 2012.

[6] Geertz, Clifford, The Interpretation of Culture, New York: Basic Books, Inc., Publisher, 1973. 
[7] U. Utari, N.S. Dedeng, S. Dan Akbar, Pembelajaran Tematik Berbasis Kearifan Lokal di Sekolah Dasar dalam Menghadapi Masyarakat Ekonomi Asean (MEA), Jurnal Teori dan Praktid Pembelajaran IPS 1 (1) (2016) 39-44.

[8] Panjaitan, dkk, Korealasi Kebudayaan dan Pendidikan Membangun Pendidikan Berbasis Budaya Lokal, Jakarta: Pusat Obor Indonesia, 2012.

[9] Silberman, L. Melvin, Active Learning 101 Cara Bealajar Siswa Aktif, Bandung: Nuansa, 2006.

[10] Cherney, D. Isabelle, The Effects of Active Learning on Student' Memories for Course Content. Journal of Active Learning in Higher $\begin{array}{llll}\text { Education } & 9 & \text { (2) (2008) 152-171. }\end{array}$ https//alh.sagepub.com/cgi/content/abstract/9/2/152.

[11] Meyers, Chet, Jones, B. Thomas, Promoting Active Learning, Jossey-Bass Publisher: San Fransisco, 1993.

[12] Prince, Michael, Does Active Learning Work: a Review of the Recearch, Deparment of Chemical Engineering Bucknell University, Journal Engr, Education 93 (3) (2004) 223-2231.

[13] S.D. Djanali,, Pengembangan Inovasi Pendidika, Jakarta: Ditjen Dikti Depdiknas Hubungannya dengan Pendidikan. Yogyakarta: FKSS IKIP Yogyakarta, 2007.

[14] Richard, JC, Rodgers T, Approaches and Methods in Language Teaching, Cambridge: Cambridge University Press, 2002.
[15] B. Tomlinson, Masuhara (Eds), Developing Language Course Materials, Singapore: RELC Portfolio Series, 2004.

[16] Borg, Walter R. dan Gall, Meredith Damien, Educational research: An Introduction, New York: Longman, 2003.

[17] Sukmadinata, Nana Syaodih. 2010. Metode Penelitian Pendidikan. Bandung: Remaja Rosdakarya.

[18] Nurkamto, Joko, "Struktur Penelitian dan Penulisan R \& D Bidang Pendidikan (Versi Borg dan Gall)", Makalah Kuliah Umum Program Pascasarjana IKIP PGRI Madiun: 30 September 2012, 2012.

[19] Miles, Matthew B. dan Huberman, A. Michael, Analisis Data Kualitatif, (terj. Tjetjeo Rohendi Rohidi)), Jakarta: universitas Indonesia, 1992.

[20] H.B. Sutopo, Metodologi Penelitian Kualitatif, Surakarta: Sebelas Maret Univercity Press, 2002.

[21] Cohen, Louis et al, Research Method in Education, Great Briatin: TJ International Ltd, Padstow, Cornwall, 2000.

[22] Wiersma, William, Research Methods in Education.: An Introduction, Boston: Allyn and Bacon, Inc, 1986.

[23] Sugiyono, Metode Penelitian Kuantitatif dan R \& D, Bandung: Alfabeta, 2013. 